\title{
THE LAW OF THE JUNGLE: AdVOCATING FOR ANIMALS IN AUSTRALIA
}

\author{
DAVID GLASGOW*
}

\begin{abstract}
A movement of activist 'animal lawyers' has recently arrived in Australia. This article contends that Australian lawyers have a significant role to play in advancing the animal protection cause. Part I discusses the philosophical foundation of the modern animal protection movement and describes the important theoretical divide that splits it into animal 'welfare' and animal 'rights'. Part II explains the Australian legal regime governing animal protection to show how the law acts as a site of exploitation. Part III explores the role of lawyers within the movement. It does this by appraising the obstacles in the way of animal protectionism and exploring what makes an effective lawyer advocate. It then uses a case study of battery hens to demonstrate the valuable role lawyers can play to support the animal cause.
\end{abstract}

We are now at a new and strange juncture in human experience. Never has there been such massive exploitation of animals... At the same time, never have there been so many people determined to stop this exploitation. ${ }^{1}$

Laws relating to animals have existed for centuries. However, a movement of activist 'animal lawyers' has only recently arrived in Australia. This movement seeks to advocate for animals and challenge deficiencies in laws that adversely impact upon them. There has been a surge of animal law activity in recent years, signalling the birth of the movement in Australia. A few examples include the rise of law schools teaching Animal Law; ${ }^{2}$ the advent of organisations such as Voiceless, ${ }^{3}$ the Barristers Animal Welfare

\footnotetext{
* BA/LLB (First Class Honours), Melbourne (2007). The author would like to thank John Tobin and an anonymous reviewer for their helpful comments on a draft of this article.

1 Wayne Pacelle, 'Law and Public Policy: Future Directions for the Animal Protection Movement' (2005) 11 Animal Law 1, 1.

${ }^{2}$ Voiceless, Where to study animal law (2007) Voiceless $<$ http://www.voiceless.org.au/index. php?option=com_content\&task=view\&id=366\&Itemid=312> at 1 June 2008. These include, among others, the University of New South Wales, Griffith University, Bond University, and the University of Sydney.

${ }^{3}$ Voiceless $<$ http://www.voiceless.org.au/> at 1 June 2008.
} 
Panel $^{4}$ and Lawyers for Animals; ${ }^{5}$ major national law firms conducting pro bono work relating to animal welfare ${ }^{6}$ and increased animal activism amongst law students through the Voiceless Animal Advocates program. ${ }^{7}$ Given this flurry of activity and the likely persistence of the cause into the future, it is important to reflect on the nature of the broader animal protection movement and the specific role of lawyers within it.

The central thesis of this paper is that Australian lawyers have a significant role to play in advancing the animal protection cause. It is therefore necessary to ask three primary questions: (1) What is the animal protection cause? (2) How is the law relevant to the cause? (3) What can Australian lawyers do to support the cause?

Accordingly, this paper is divided into three parts corresponding to the three primary questions. Part I answers the first question. It discusses the origin and philosophical foundation of the modern animal protection movement and describes the important theoretical divide between animal 'welfare' and animal 'rights' that currently splits the movement. Initial thoughts will be offered on how this theoretical debate should proceed into the future. Part II answers the second question. It briefly charts the rising involvement of lawyers in support of the cause overseas. It also discusses the legal regime governing animal protection in Australia to show how the law acts as a site of animal exploitation. With the background in Part I and II having been surveyed, Part III expounds the central thesis by answering the third question. In order to determine the role of lawyers in assisting the cause, it appraises the obstacles in the way of the animal protection movement and explores what makes for an effective lawyer advocate. It then uses a case study of battery hens to illuminate the earlier, more academic, discussion.

\section{What is the Animal Protection Cause?}

The notion that animals are inferior to humans has a long history. Whether reflected in the Judeo-Christian view that humans have 'dominion' over all other forms of life ${ }^{8}$ or in the Aristotelian conception of animals as existing for the sake of humanity, ${ }^{9}$ the moral inferiority of animals is deeply embedded in our culture. For much of Western history, animals were thought to have no

\footnotetext{
${ }^{4}$ Barristers Animal Welfare Panel $<$ http://www.vicbar.com.au/e.1.12.asp > at 1 June 2008.

${ }^{5}$ Lawyers for Animals $<$ http://lawyersforanimals.org.au/ $>$ at 1 June 2008.

${ }^{6}$ Clare Buttner, 'Leading the way on animal welfare' Lawyers Weekly, 11 May 2007, 14-5.

${ }^{7}$ Voiceless Animal Advocates $<$ http://www.vaa.org.au> at 1 June 2008.

${ }^{8}$ Genesis 1:26.

${ }^{9}$ Aristotle, 'Politics' in Jonathan Barnes (ed), The Complete Works of Aristotle (1984) 1993-4.
} 
direct moral claim on humans. In support of this, philosopher Immanuel Kant argued that animals were nothing but a means to human ends. ${ }^{10}$ Even today, the very fact that the word 'animal' is used in contradistinction to 'human' reflects the pervasive influence of the notion that humanity is separate to and above the rest of the natural world.

At least two events provided the catalyst for a new understanding of animal ethics. One was the publication of Charles Darwin's Origin of Species, which emphasised the continuity between humans and other species and displaced the creationist foundations of the earlier hierarchical views. ${ }^{11}$ The other was the moral claim of eighteenth century utilitarian philosopher Jeremy Bentham. Bentham argued that an individual's capacity for suffering is what matters morally, not the capacity for reason or speech. We have direct obligations towards animals simply because, like humans, they can suffer. ${ }^{12}$

A Benthamite recognition of animal sentience led to the enactment in the nineteenth and twentieth centuries of animal welfare statutes that prohibited the infliction of suffering in narrowly defined circumstances. ${ }^{13}$ However, it was not until the rise of other social justice movements in the 1960s and 70s that a more radical ethic with regard to animals was introduced into public discourse.

\section{A Birth of the Modern Movement}

James Jasper and Dorothy Nelkin argue that philosophers 'served as midwives' of the animal protection movement in the late 1970s. ${ }^{14}$ Indeed, it is difficult to deny the considerable support shown towards animal protectionism by philosophy academics in the last few decades. ${ }^{15}$ A brief outline of the two most influential animal ethics philosophers is necessary in order to understand both how the animal protection movement began and why it is currently split into the factions discussed in Part IB. The following outline is not intended to argue for the truth of the philosophers' views, but rather to provide a greater theoretical understanding of the movement.

\footnotetext{
${ }^{10}$ Immanuel Kant, Lecture on Ethics, (translated by L Infield, 1963) 239-40.

${ }^{11}$ Roger S Fouts, 'Apes, Darwinian Continuity, and the Law' (2004) 10 Animal Law 99, 1023.

${ }^{12}$ Gary L Francione, Introduction to Animal Rights: Your Child or the Dog? (2000) 5.

${ }^{13}$ For a history of Australian animal welfare laws, see Philip Jamieson, 'Duty and the Beast: The Movement in Reform of Animal Welfare Law' (1991) 16 University of Queensland Law Journal 238.

${ }^{14}$ James M Jasper and Dorothy Nelkin, The Animal Rights Crusade: The Growth of a Moral Protest (1992) 90.

${ }^{15}$ Peter Singer, Animal Liberation $\left(2^{\text {nd }}\right.$ ed, 1995), 241-2.
} 


\section{$1 \quad$ Peter Singer}

The publication of Peter Singer's Animal Liberation in 1975 is often thought to have launched the modern animal protection movement. Singer is a consequentialist, so he believes that the morally correct action is that which brings about the best overall consequences for all those affected by the action. As a preference utilitarian, Singer believes that the best consequences are brought about by maximising the satisfaction of preferences, such as the preference to avoid pain or the preference to continue living. In order to determine the best overall consequences, Singer argues that we must use the principle of equal consideration of interests. That is, 'the interests of every being affected by an action are to be taken into account and given the same weight as the like interests of any other being, ${ }^{16}$

Singer argues that animals have a 'like interest' with humans in one important respect: they have an interest in avoiding suffering. If we fail to equally consider an animal's interest in not suffering and a human's interest in not suffering, we are guilty of 'speciesism.' This is similar to racism and sexism; however, instead of an arbitrary prejudice towards those with a particular skin colour or sex, it is an arbitrary prejudice in favour of our own species against other species. ${ }^{17}$ For example, let us consider a man who slaps a baby with his open palm. The man then whacks a horse with a large stick, so as to cause the horse the same amount of pain as that experienced by the baby. Singer argues that 'if we consider it wrong to inflict that much pain on a baby for no good reason then we must, unless we are speciesists, consider it equally wrong to inflict the same amount of pain on a horse for no good reason'. ${ }^{18}$

Singer's arguments lead to radical conclusions about the way we treat animals. For example, if we must consider equally the interests of animals and humans in not suffering, it is difficult to justify the cruelty involved in intensive farming. Similarly, we could not justify painful scientific experiments on animals unless we would be willing to inflict the same amount of pain on human subjects. However, as a utilitarian, Singer does not believe that animals have 'rights' per se. All that matters, morally speaking, is that the best overall consequences are brought about after equally considering the interests of all those affected by your action. Therefore,

\footnotetext{
${ }^{16}$ Ibid 5 (emphasis added).

${ }^{17}$ Ibid 6.

${ }^{18}$ Ibid 15.
} 
neither animals nor humans have inviolable rights. This places Singer at odds with the second most influential animal ethicist, Tom Regan.

\section{Tom Regan}

In contrast to the utilitarian ethics of Peter Singer, American philosopher Tom Regan argued for a rights-based approach to animals in his 1983 work, The Case for Animal Rights. ${ }^{19}$ Regan argues that humans and some animals are 'subjects-of-a-life'. That is, they possess qualities such as beliefs, desires, perception, memory, emotions, and an 'experiential life' in which they may fare well or badly 'logically independently of their utility for others' ${ }^{20}$ Regan believes that at least all normal mammals aged one year and over will satisfy his subject-of-a-life criterion. All subjects-of-a-life have 'equal inherent value' and an 'equal prima facie right not to be harmed'. ${ }^{21}$

Recognising the intrinsic value of humans and some animals entails recognising that they cannot be used as means to an end, regardless of whether the best overall consequences will be secured by such treatment. In taking this stance, Regan departs from the utilitarian ethics of Singer, arguing instead that all instrumental use of animals for such things as food, hunting and vivisection is wrong. ${ }^{22}$

Of course, Singer himself regards most instrumental use of animals as unethical. However, this is because Singer believes the utilitarian calculus of the best overall consequences is not satisfied in relation to most uses of animals. Regan, by contrast, believes the instrumental use is itself a violation of animals' intrinsic value.

\section{B Theoretical Debates}

The influence of Singer and Regan on the animal protection movement is evident in the persistent division between supporters of animal welfare and supporters of animal rights. This division reflects fundamentally different ways of understanding the moral status of animals and the ethics of human practices that affect them.

\footnotetext{
${ }^{19}$ Tom Regan, The Case for Animal Rights (1983).

${ }^{20}$ Ibid 243.

${ }^{21}$ Ibid 329.

${ }^{22}$ Gary L Francione, 'Animal Rights and Animal Welfare' (1996) 48 Rutgers Law Review 397, 419.
} 


\section{$1 \quad$ Animal Welfare}

Animal welfare is concerned with the humane regulation of animal use. It takes as its starting point the moral legitimacy of current institutional use of animals. ${ }^{23}$ For this reason welfarists do not seek to abolish human use of animals for food, sport, entertainment, fashion or science. Rather, welfarists argue that we need to ensure that we treat animals 'humanely' within those institutions. ${ }^{24}$ The primary aim of welfare supporters is to abolish 'unnecessary' suffering within the accepted paradigms of the animals' use. For example, welfarists are likely to oppose the confinement of pregnant sows to narrow crates on the basis that it is unnecessary, but have no problem with the farming of pigs for their meat per se. Welfarists also tend not to be concerned with the legal status of animals as property; ${ }^{25}$ indeed some argue that commodifying animals by designating them as property can be 'liberating' for the animals, because people protect what they own. ${ }^{26}$

Animal welfare is the underpinning philosophy of the RSPCA. On its website the RSPCA states that it 'does not oppose the farming of animals. We just think they should be given a fair go'. The RSPCA believes that 'if the animal is to be slaughtered, it should be done quickly and humanely'. ${ }^{27}$ As will be shown in Part IIB, animal welfare is also the underpinning philosophy of Australian animal protection statutes.

\section{$2 \quad$ Animal Rights}

The animal rights view provides a more radical and structural critique of current practices relating to animals. It supports the eventual abolition of all human use of animals. ${ }^{28}$ Animal rights supporters charge animal welfarists with inconsistency by arguing that it is arbitrary to limit the concept of 'unnecessary suffering' to practices within the institutional status quo. The institutions (such as using animals for food) are themselves unnecessary. Animal rights advocates seek to abolish the property status of animals, arguing that only by according animals legal personhood can their interests

\footnotetext{
${ }^{23}$ Jerrold Tannenbaum, 'Animals and the law: property, cruelty, rights' (1995) 62 Social Research 539, 575.

${ }^{24}$ Francione, above n 23, 397-8.

${ }^{25}$ See, eg, Robert Garner, 'Political Ideology and the Legal Status of Animals' (2002) 8 Animal Law 77.

${ }^{26}$ Richard A Posner, 'Animal Rights' (2000) 110 Yale Law Journal 527, 539.

${ }^{27}$ RSPCA, Fair Go for Farm Animals <http://www.rspca.org.au/campaign/fairgo.asp $>$ at 1 June 2008.

${ }^{28}$ Cass R Sunstein, 'Introduction: What Are Animal Rights?' in Cass R Sunstein and Martha C Nussbaum (eds), Animal Rights: Current Debates and New Directions (2004) 4-5.
} 
be adequately protected. ${ }^{29}$ Despite these counter-cultural aims, many animal rights supporters use a welfarist approach in their advocacy and campaign strategies, based on the belief that a rights approach is utopian and unachievable in the short term, and that incremental steps of humane regulation will lead to animals eventually being granted rights. ${ }^{30}$ Other animal rights supporters, such as legal academic Gary Francione, strongly criticise this view and insist on the pursuit of an 'abolitionist' agenda and the wholesale rejection of welfarism. ${ }^{31}$

Animal rights is the underpinning philosophy of People for the Ethical Treatment of Animals (PETA). PETA argues that animals are not ours to eat, wear, experiment on or use for entertainment. ${ }^{32}$ Similarly, Animal Liberation Victoria aims to 'abolish, and not merely regulate, institutionalised animal exploitation'. ${ }^{33}$

The welfare/rights divide can be traced back to the philosophical variance between Peter Singer and Tom Regan. Regan unequivocally opposes institutions that use animals on the basis that this violates the rights of animals as bearers of intrinsic value. Singer is more ambivalent towards institutional use of animals and does not believe animals strictly have rights. However, because Singer believes that the interests of animals and humans in not suffering ought to be considered equally, his views are more radical than some advocates of the animal welfare view. ${ }^{34}$

\section{$3 \quad$ Care Ethics}

Of course, welfare and rights are not the only philosophical frameworks for animal ethics. A noteworthy competing school of thought is 'care ethics', exemplified in the work of ecofeminist Carol Adams. ${ }^{35}$ On this approach,

\footnotetext{
${ }^{29}$ Alan Watson, 'Rights of Slaves and Other Owned-Animals' (1997) 3 Animal Law 1, 6.

${ }^{30}$ Jonathan R Lovvorn, 'Animal Law in Action: The Law, Public Perception, and the Limits of Animal Rights Theory as a Basis for Legal Reform' (2006) 12 Animal Law 133, 139 and 142; Gary L Francione, Rain Without Thunder: The Ideology of the Animal Rights Movement (1996) 35.

${ }^{31}$ See, eg, Gary L Francione, 'Animal Rights Theory and Utilitarianism: Relative Normative Guidance' (1997) 3 Animal Law 75; Francione, above n 23.

${ }^{32}$ People for the Ethical Treatment of Animals $<\mathrm{http}: / / \mathrm{www}$.peta.org/> at 1 June 2008.

${ }^{33}$ Animal Liberation Victoria, About $A L V<\mathrm{http}: / /$ www.alv.org.au/about.php $>$ at 1 June 2008.

${ }^{34}$ For more information on animal welfare and animal rights, see, eg, Robert Garner, 'Animal Welfare: A Political Defense' (2006) 1 Journal of Animal Law and Ethics 161; Francione, above $\mathrm{n} 23$.

${ }^{35}$ Josephine Donovan and Carol J Adams (eds), Beyond Animal Rights: A Feminist Caring Ethic for the Treatment of Animals (1996).
} 
rights are patriarchal and establish hierarchies between those who have rights and those who do not. Further, this approach argues that most rights and welfare models focus too heavily on abstract, rational concepts rather than integrating sentiments into their theories. ${ }^{36}$ Care ethicists argue that we should reject these abstract theories in favour of a more contextualised approach based on compassion. For example, one writer argues that we have moral duties to some animals because we enter into relations with them that make them dependent on us for their well-being, not because animals have rights or because we want to maximise utility. ${ }^{37}$

In a similar vein, conservative Christian writer Matthew Scully argues that concern for animals should be based on human 'mercy' towards the vulnerable rather than the equalitarian arguments of philosophers such as Singer. ${ }^{38}$ Rather than rejecting the notion of human superiority, Scully argues that we are simply 'abusing dominion, the first and greatest power given to man on earth'. ${ }^{39}$ The remedy is human compassion rather than animal liberation.

\section{$4 \quad$ Ecocentric Perspectives}

Other theorists extend the moral circle even further than non-human animals, to include 'soils, waters, plants, and animals, or collectively: the land'. ${ }^{40}$ Proponents of ecocentrism argue that animals (including humans) are 'just one constituency among others in the biotic community, just one particular strand in the web of life'. ${ }^{41}$ Accordingly, ecocentrism rejects the moral individualism of the other theories in favour of a more holistic view. Individual animals should not be the focus of our ethical concern. Rather, we should protect the integrity of ecological functioning because ecosystems have intrinsic value. ${ }^{42}$ Because ecocentrism focuses on the system, rather than

\footnotetext{
${ }^{36}$ See, eg, Thomas G Kelch, 'The Role of the Rational and the Emotive in a Theory of Animal Rights' (1999) 27 Boston College Environmental Affairs Law Review 1, 41.

${ }^{37}$ Daniel Engster, 'Care Ethics and Animal Welfare' (2006) 37 Journal of Social Philosophy 521,521 and 527.

${ }^{38}$ Matthew Scully, Dominion: The Power of Man, the Suffering of Animals, and the Call to $\operatorname{Mercy}(2002) 20$.

${ }^{39}$ Ibid 24.

${ }^{40}$ Aldo Leopold, A Sand Country Almanac and Sketches Here and There (1949) 204.

${ }^{41}$ Warwick Fox, 'Deep Ecology: A New Philosophy of Our Time' (1984) 14 The Ecologist 194.

${ }^{42}$ Ross Ramsay and Gerard C Rowe, Environmental Law and Policy in Australia: Text and Materials (1995) 16-32.
} 
the individuals within the system, Tom Regan notoriously dubbed this view 'environmental fascism'. 43

\section{Where to for Theory?}

Despite the diversity of theoretical perspectives, welfare and rights have emerged as the dominant models. The distinction between the two is not merely academic. Forming an opinion on the theory will affect the nature of the advocacy undertaken by lawyers and other supporters of the movement. First, it will affect the sort of projects considered worthwhile undertaking. Welfare proponents may consider it valuable to advocate for more cage space for battery hens, while rights proponents will probably only support the cage's abolition. Second, it will affect the nature of the arguments employed. Rights proponents will argue that animals have a right not to be experimented upon, while welfare proponents will simply argue that some experimentation practices are unnecessarily cruel. Third, it will affect beliefs on how we should respond to animal cruelty in our individual lives. Welfare proponents may support eating meat that is sourced from organic or free-range farms, while rights proponents are likely to support the adoption of a vegan diet. Fourth, the split currently affects the ability of the movement to advocate effectively. The movement is more powerful if it is able to present a united front in its campaigns against animal exploitation. ${ }^{44}$ This is compromised by the internal division between welfare supporters and rights supporters.

It is important to resolve the welfare/rights debate not only because it compromises internal unity, but also because, if rights advocates like Gary Francione are correct, welfarism is actually having a negative effect on the long-term success of the movement. ${ }^{45}$ This is a long-standing division, so attempting to reach a resolution in a single paper is impossible. Instead, this paper intends to move the theoretical debate in a slightly different direction. Some reflections on problems with both welfare and rights theory will be discussed, followed by a brief sketch of how some convergence between welfare and rights may be achieved using the work of American scholar Martha Nussbaum.

\footnotetext{
${ }^{43}$ Regan, above $\mathrm{n} 20,361-2$.

${ }^{44}$ Sarah Maddison and Sean Scalmer, Activist Wisdom (2006) 117.

${ }^{45}$ Lesli Bisgould, 'Animal Oppression and the Pragmatist' (1997) 3 Animal Law 39, 40-1; Gary L Francione, Rain Without Thunder: The Ideology of the Animal Rights Movement (1996) 6.
} 


\section{$1 \quad$ Problems with Current Theories}

Both animal welfare and animal rights are too universalist. ${ }^{46}$ The main problem is their use of the term 'animal', which is largely meaningless as a concept. In common parlance, usually a distinction is drawn between 'humans' and 'animals', with everything from an oyster to a chimpanzee placed in the latter category, despite the fact that humans are much more similar to chimpanzees than chimpanzees are to oysters. ${ }^{47}$

Speaking of 'animal' rights or 'animal' welfare as though animals are an undifferentiated class is highly problematic for two main reasons. First, it allows opponents of the movement to caricature animal advocates as favouring fanciful projects such as the liberation of mosquitoes. ${ }^{48}$ These reactionary views aimed at denoting animal advocates as extremists have some currency in public debate. This eclipses the strong arguments of the movement on issues such as factory farming, vivisection, live exports and so on. Second, the term 'animal' is conceptually incoherent when referring to rights or welfare. Different animals (including humans) have different needs, desires and levels of consciousness. Some species are social and need opportunities for interaction, exercise and play. Other species are solitary or sedentary and therefore have different needs. Some species do not have a central nervous system or a brain; it is questionable whether we owe individuals within such a non-sentient species any moral obligations. Others, such as great apes, have a highly developed consciousness and ability to suffer, so our obligations towards them may be quite substantial. As James Rachels argues: ${ }^{49}$

There is no such thing as moral standing simpliciter. Rather, moral standing is always moral standing with respect to some particular mode of treatment. A sentient being has moral standing with respect to not being tortured. A self-conscious being has moral standing with respect to not being humiliated. An autonomous being has moral standing with respect to not being coerced.

\footnotetext{
${ }^{46}$ Lesley J Rogers and Gisela Kaplan, 'All Animals are Not Equal: The Interface Between Scientific Knowledge and Legislation for Animal Rights' in Cass R Sunstein and Martha C Nussbaum (eds), Animal Rights: Current Debates and New Directions (2004) 175.

${ }^{47}$ Singer, above $\mathrm{n} 16$, xiv.

${ }^{48}$ Steven M Wise, 'Thunder Without Rain: A Review/Commentary of Gary L Francione's Rain Without Thunder: The Ideology of the Animal Rights Movement' (1997) 3 Animal Law 45,50 .

49 James Rachels, 'Drawing Lines' in Cass R Sunstein and Martha C Nussbaum (eds), Animal Rights: Current Debates and New Directions (2004) 170 (emphasis added).
} 
Therefore, rather than speaking of 'animal' rights or 'animal' welfare, we should speak specifically of gorilla rights, pig rights, dolphin rights and so on. These rights or welfare interests are likely to differ considerably from species to species. When discussing animal rights, we should always ask: which animal? And which rights?

Of course, few animal advocates would contend that every animal, regardless of its species or circumstances, should have exactly the same entitlements. However, this nuance quickly collapses into the absolutism of 'animal' rights/welfare in public discourse. Activists should make a more concerted attempt to particularise their theories, claims and arguments to the individual circumstances and species about which they are campaigning. ${ }^{50}$ Such an attempt to particularise animals' entitlements and move beyond the universalism of animal 'rights' and animal 'welfare' is found in the work of philosopher Martha Nussbaum.

\section{$2 \quad$ Capabilities Approach}

Nussbaum supports a political and moral theory known as the capabilities approach, which is roughly based on the work of Aristotle and was popularised by Amartya Sen in the field of welfare economics. ${ }^{51}$ The capabilities approach, in its application to humanity, argues that every human 'strives for a good, which is the exercise and maintenance of its characteristic form of life'. ${ }^{52}$ We can ethically evaluate certain capabilities as valuable, 'those without which a life would not be fully human'. ${ }^{53}$ These could include, for example, the ability to play, to reason, and to have relationships with other humans. ${ }^{54}$ Once we have a list of basic capabilities, people have a justified claim against individuals and governments that they "not be stunted or wasted, but given a chance to develop. ${ }^{55}$

To illustrate, let us say that we, as a society, determine that freedom of movement is a basic capability, without which we cannot strive for a good or become fully human. It would be wrong for an individual or government to

\footnotetext{
${ }^{50}$ Peter Singer, 'The Legal Status of Nonhuman Animals' (2002) 8 Animal Law 1, 25.

${ }^{51}$ Amartya Sen, 'Capability and Well-Being' in Martha Nussbaum and Amartya Sen (eds), The Quality of Life (1993) 30.

${ }^{52}$ Martha C Nussbaum, 'Book Review: Animal Rights: The Need For a Theoretical Basis' (2001) 114 Harvard Law Review 1506, 1535.

${ }^{53}$ Ibid.

${ }^{54}$ Steven White, 'Animals and the Law: A New Legal Frontier?' (2005) 29 Melbourne University Law Review 298, 307-8.

${ }^{55}$ Nussbaum, above n 53, 1536.
} 
restrict this freedom, for instance by arbitrarily preventing someone from moving house. Similarly, let us suppose that the capability to use practical reason is deemed a valuable human good. Governments would need to provide their people with basic levels of education to allow them the literacy and numeracy to exercise their capacity for practical reason. As these examples clarify, sometimes the capabilities approach will require positive intervention to lay the groundwork for the capability to flourish, such as by providing healthcare or education. On other occasions, the capabilities approach will require that individuals and governments simply leave others alone.

The capabilities approach is similar to a rights-based view, and could be partly analysed as arguing for the provision of both positive and negative human rights. It contends that "providing support for these capabilities, up to a threshold level, is a central task of the nation-state'. ${ }^{56}$ This approach offers a theoretical foundation for respecting and promoting human rights, because failure to do so robs us of the very things that support human flourishing and make us who we are.

Martha Nussbaum points out that animals also have a characteristic way of life and a set of capabilities. They pursue pleasure and avoid pain, exercise, eat, drink, play and form social bonds with other animals, to name only a few. For example, chickens form social 'pecking orders' and will naturally derive pleasure from dust bathing, perching and scratching around in the dirt. Thwarting these behaviours by confining hens to battery cages for their entire lives is unethical on the capabilities approach, because it precludes the hens from pursuing their way of life, ie the basic capabilities that make up their nature as chickens.

Crucially, capabilities will differ from species to species, and therefore our obligations towards them will also differ. Steven Wise takes great apes as an example: ${ }^{57}$

[C]himpanzees and bonobos are likely aware of themselves, of their environment, and of the future and past. They have wishes and desires and a complex family-based structure. Their culture and learning may be passed from one generation to the next within families. To forcibly remove chimpanzees and bonobos from their natural environment or to maintain them in artificial environments for human purposes is usually to deny them

\footnotetext{
${ }^{56}$ Ibid.

${ }^{57}$ Steven M Wise, 'Legal Rights for Nonhuman Animals: The Case for Chimpanzees and Bonobos' (1996) 2 Animal Law 179, 185.
} 
their culture and their ability to form important and social relationships. This deprives them of a substantial portion of what gives meaning to their lives.

Other species that do not have the cognitive or relational capabilities of great apes may not be deprived of anything valuable by being kept in human environments, for example as pets. Thus, what may be considered a gross violation of animal capabilities in one context may be perfectly legitimate in another. This creates ambiguity but is more realistic than the false certainty provided by universalist views.

In order to determine the nature of animal capabilities, reference to 'current scientific knowledge on the biology and behavior of different species' is required. ${ }^{58}$ Ethical evaluation is also necessary to determine what contributes to the flourishing and well-being of the characteristic form of life experienced by different species.

Aside from the universality of the two major theories, the capabilities approach is superior to the animal welfare and animal rights approaches for other reasons. The welfare approach is inadequate because it provides no structural or institutional critique of practices that harm animals. On Peter Singer's utilitarian approach, welfarism also fails to treat individual animals as ends rather than means, preferring instead to pursue the overall best consequences even if it means deprivation of the interests of some individuals. The rights approach is inadequate because it is too simplistic. Gary Francione argues that all sentient animals should have only one right: the right not to be treated as things. ${ }^{59}$ The capabilities approach has the advantage of being more nuanced, and recognising that different animals may have different rights, depending on what contributes to their unique ways of living. In fact, some animals may not have any rights at all. Whereas the rights approach seeks to abolish all institutions that use animals for human purposes, the capabilities approach is not so absolutist. Some institutions that respect animal capabilities may be acceptable, while others may need to be eradicated.

Despite the superiority of the capabilities approach at a theoretical level, there are some potential problems with its implementation into law. Because it differs from species to species and requires constant revision as new scientific evidence comes to light, it may create considerable complexity

\footnotetext{
${ }^{58}$ Rogers and Kaplan, above n 47.

${ }^{59}$ Francione, above n 13, xxix.
} 
from a regulatory point of view. Obviously, as Nussbaum herself recognises, more academic work needs to be done around the application of the capabilities approach to animals. Which capabilities should be considered valuable? To what extent are individual humans and governments required to promote animal capabilities? How can capabilities be supported at a legislative level without creating a convoluted regulatory maze? These are difficult questions that require ongoing debate and discussion. However, such discussion will hopefully lead to a more fruitful theoretical basis for animal advocacy than the simplistic doctrines of animal welfare or rights.

\section{How is the Law Relevant to the Cause?}

Part I explained the origin and philosophy of the modern animal protection movement. It noted the profound influence of Peter Singer and Tom Regan and the present-day split between supporters of animal welfare and proponents of animal rights. A sketch was then provided of an alternative to the welfare/rights dichotomy in the form of Nussbaum's capabilities approach. By now, the first primary question of this paper should be answered: what is the animal protection cause? In this Part, the second primary question will be resolved: how is the law relevant to the cause?

It did not take long after the meteoric rise of the animal protection movement for activists to realise that law is a crucial site of animal exploitation. The law institutionalises and routinely excuses animal cruelty and has erected what sometimes seems an impenetrable barrier to effective change. Indeed, animals are lawfully 'starved, terrorised, beaten, confined, abused and violated' ${ }^{60}$ In this Part, a brief outline will be given of the rise of 'animal law' within the United States. Then, a few basic problems with the legal regime governing animals in Australia will be discussed. The inadequacy of Australian animal statutes should clearly show why the law is a crucial site for advocacy and agitation.

\section{A The Rise of Animal Law}

In recognition of the importance of law to the goals of the animal protection movement, activist animal lawyers and the discipline of 'animal law' emerged in the United States soon after the arrival of the broader movement itself. Legal scholars such as Steven Wise, David Favre and Gary Francione planted the seeds that have blossomed into over 90 American animal law courses, the Animal Legal Defense Fund, scholarly journals and textbooks

${ }^{60}$ Katrina Sharman, ‘An emerging field’ (2006) 31 Alternative Law Journal 227, 229. 
dedicated to animal law, animal law bar associations, conferences, seminars, inter-university competitions and student groups. ${ }^{61}$ Prominent universities including Harvard and Stanford teach animal law, a testament to how mainstream it has become. ${ }^{62}$

Animal law has also made its mark elsewhere, with courses available in New Zealand, Canada, the UK, Switzerland, Israel and China. ${ }^{63}$ Germany became the first country to officially recognise animals as worthy of protection in its national Constitution. ${ }^{64}$ However, despite its long-standing status in the United States and growing status elsewhere, Australian lawyers have only recently become involved in the animal law juggernaut, as outlined at the beginning of this paper. Disappointingly, though, the treatment of animals in Australia and the defects in our animal laws are no less dire than in the United States.

\section{$1 \quad$ Animal Protection Law in Australia}

'Animal' is usually defined in legislation so as to exclude humans from the definition, reflecting a hierarchical, pre-Darwinian metaphysics. ${ }^{65}$ Domestic animals, including farm animals, are the absolute property of their owners. Property in wildlife, however, is vested in the Crown but can be transferred to others through a licensing scheme. ${ }^{66}$ As such, the law primarily constructs animals as instruments for the use and enjoyment of humans. Yet the law thankfully recognises that animals, unlike inanimate objects, have interests in avoiding suffering that ought to be protected. The discussion below will mainly concentrate on farm animals, but many of the arguments also apply to animals used for other purposes.

\footnotetext{
${ }^{61}$ Laura Ireland Moore, 'A Review of Animal Rights: Current Debates and New Directions' (2005) 11 Animal Law 311, 312; Geoff Bloom, 'Animal law graduates to legal discipline: anyone interested in an LLM (Animal Law)?' (2004) 42(5) Law Society Journal 19, 19-20; White, above n 55, 299.

${ }^{62}$ Animal Legal Defense Fund, Animal Law Courses (2007) <www.aldf.org/content/index. php?pid=83 $>$ at 1 June 2008 .

${ }^{63}$ Voiceless, above $\mathrm{n} 3$.

${ }^{64}$ Article 20a of the German Basic Law. See Kate Nattrass, ““... Und Die Tiere”: Constitutional Protection for Germany's Animals' (2004) 10 Animal Law 283.

${ }^{65}$ See, eg, Environment Protection and Biodiversity Conservation Act 1999 (Cth) s 528, which defines 'animal' as 'any member, alive or dead, of the animal kingdom (other than a human being)'.

${ }^{66}$ Butterworths, Halsbury's Laws of Australia (at 17 October 2007) 20 Animals, '1 Property in Animals' [50].
} 
As there is no federal constitutional power over animals, the treatment of animals is primarily governed by welfare statutes in the States and Territories. ${ }^{67}$ There is also specific legislation governing certain types of animals, such as the Animal Research Act 1985 (NSW) and the Wildlife Act 1975 (Vic). Each State's primary animal welfare statute prohibits narrowly defined acts of cruelty on animals. For example, Queensland law makes it an offence for anyone to cause an animal pain that, in the circumstances, is 'unjustifiable, unnecessary or unreasonable'. ${ }^{68}$ Offences so framed are obviously imprecise and allow for plenty of definitional wriggle room. One person's conception of 'unnecessary' or 'unreasonable' pain can be dramatically different from another's.

Significantly, most animals are expressly excluded from the statutes' protection and governed instead by 'Codes of Practice'. For example, section 6 of the Victorian Act states that the Act does not apply to 'any act or practice with respect to the farming, transport, sale or killing of any farm animal which is carried out in accordance with a Code of Practice'. ${ }^{69}$ Thus, hundreds of millions of animals every year are excluded from our animal welfare laws. This means the statutes' usefulness is largely limited to isolated acts of cruelty committed against domestic pets, as opposed to large-scale systemic cruelty in institutions of food, science and sport.

The Codes of Practice do not provide adequate protection for Australia's farm animals (or any other class of animals governed by Codes). They are created under the auspices of the Primary Industries Ministerial Council, whose self-described objective is 'to develop and promote sustainable, innovative and profitable agriculture, fisheries/aquaculture, food and forestry industries'. ${ }^{70}$ There are no animal welfare representatives on the Committee that creates the Codes; rather, the RSPCA and Animals Australia are merely 'consulted' during the process. ${ }^{71}$ The Codes are legally unenforceable everywhere other than South Australia, so non-compliance does not of itself

\footnotetext{
${ }^{67}$ Prevention of Cruelty to Animals Act 1986 (Vic); Prevention of Cruelty to Animals Act 1979 (NSW); Animal Welfare Act 1992 (ACT); Animal Welfare Act 1999 (NT); Animal Care and Protection Act 2001 (Qld); Prevention of Cruelty to Animals Act 1985 (SA); Animal Welfare Act 1993 (Tas); Animal Welfare Act 2002 (WA).

${ }^{68}$ Animal Care and Protection Act 2001 (Qld) s 18(2)(a).

${ }^{69}$ Prevention of Cruelty to Animals Act 1986 (Vic) s 6(1)(c).

70 Primary Industries Ministerial Council, About the PI Ministerial Council (2007) $<$ http://www.mincos.gov.au/about_pimc > at 1 June 2008

${ }^{71}$ Primary Industries Standing Committee, Model Code of Practice for the Welfare of Animals: Cattle (2 $2^{\text {nd }}$ ed, 2004) Preface.
} 
constitute an offence. ${ }^{72}$ Furthermore, the welfare standards within the Codes are set very low. Practices such as mulesing, castration and tail docking without pain relief continue unabated. ${ }^{73}$ In this way, acts that would constitute cruelty offences if carried out on domestic pets are given the law's imprimatur when carried out on farm animals. ${ }^{74}$

Aside from the manifest deficiencies in the Code system, Australia's animal protection statutes are also difficult to enforce. State Departments of Primary Industries are empowered to enforce the Acts against non-compliant industry groups, yet these Departments consider their 'mission' to be the maximisation of animal industry economic performance. ${ }^{75}$ Therefore, only the RSPCA is able to play a meaningful enforcement role, yet the RSPCA is sorely lacking in the requisite funds to enforce a large public interest statute. ${ }^{76}$ Enforcement is also made difficult by the low penalties for offences. In South Australia, the only State in which failure to comply with a Code of Practice is an offence, the maximum penalty for non-compliance is a mere $\$ 1,250 .^{77}$ Even in States where the maximum penalty for infringement of the main cruelty offence is over $\$ 10,000$ for corporations, ${ }^{78}$ such amounts provide inadequate deterrent for multi-million dollar companies. Power to inspect premises is also tightly curtailed in the legislation and provides high thresholds for entry, making it difficult to detect and prevent cruelty. ${ }^{79}$

Despite major shortcomings in animal law, of which only a few have been mentioned, politicians of both major parties have proven stubbornly resistant to change. In 2005, Andrew Bartlett of the Australian Democrats attempted to create a unified and consistent federal approach to animal welfare that would

72 Department for Environment and Heritage, Codes of Practice (2007) <http://www. environment.sa.gov.au/animalwelfare/codes.html> at 1 June 2008.

${ }^{73}$ Sharman, above $\mathrm{n} 61$.

${ }^{74}$ Graeme McEwen, 'Farm Animals and the Law' (Speech delivered at the New South Wales Young Lawyers Animal Law Conference, University of New South Wales, 6 July 2007) $<$ http://www.vicbar.com.au/GetFile.ashx?file=BarAssoc

AnimalWelfareFiles\%2fFarm+Animals+and+the+Law.pdf $>5$ at 1 June 2008.

${ }^{75}$ See, eg, Department of Primary Industries and Fisheries, Annual Report 2006-7 (2007) $<$ http://www.dpi.qld.gov.au/cps/rde/xbcr/dpi/AboutUs-AnnualReport0607-full.pdf $>2$ at 1 June 2008

${ }^{76}$ Graeme McEwen, 'Legal Challenges in Animal Welfare' (Speech delivered at a meeting of the Victorian Bar, Melbourne, 15 December 2006) <http://www.vicbar.com.au/GetFile.ashx? file $=$ BarAssocAnimalWelfareFiles $\% 2$ flegal + challenges + in + animal + welfare + speech + FINAL + $151106+(2)$.pdf $>12$ at 1 June 2008; RSPCA, Our Work: Inspectorate <http://www.rspca.org. au/about/ourwork_inspect.asp> at 1 June 2008.

${ }^{77}$ Prevention of Cruelty to Animals Regulations 2000 (SA) r 10.

${ }^{78}$ See, eg, Prevention of Cruelty to Animals Act 1986 (Vic) s 9(1).

${ }^{79}$ McEwen, above n 77, 8-11. 
have provided protection for animals currently excluded from state-level statutes. ${ }^{80}$ The proposed National Animal Welfare Bill 2005 (Cth) made no attempt to abolish the property status of animals, grant animals rights, or query the legitimacy of institutions that use animals for human purposes. However, the Senate Committee that examined the Bill comprehensively rejected it and expressed support for the status quo. ${ }^{81}$

It should now be clear that animal protection law in Australia embodies the welfarist rather than the rights view, ${ }^{82}$ and tepidly at that. It exempts farm animals, which is unjustifiable on principle but convenient economically, and does very little to challenge institutional cruelty. What remains of its protective ambit is difficult to enforce, and the political will to rectify the problems is sorely lacking. ${ }^{83}$

Hopefully this discussion has illustrated the relevance of the law to the animal protection cause. The need for Australian lawyers to support the movement has never been more acute. It therefore remains for Part III to explore how lawyers can bring their skills to bear for the advancement of animals.

\section{What CAN AUSTRALIAN LAWYERS Do?}

[E]ach time there is a movement to confer rights onto some new "entity", the proposal is bound to sound odd or frightening or laughable. This is partly because until the rightless thing receives its rights, we cannot see it as anything but a thing for the use of "us"- those who are holding rights at the time. $^{84}$

In this Part, the third and final primary question will be answered: what can Australian lawyers do to support the cause? In order to do this, Part III is broken into three sections. Part IIIA will appraise the obstacles in the way of the animal protection movement. Without taking stock of the barriers and

\footnotetext{
${ }^{80}$ This was to be based on the external affairs, corporations and trade and commerce powers in the Constitution: see National Animal Welfare Bill 2005 (Cth) s 5.

${ }^{81}$ Senate Rural and Regional Affairs and Transport Legislation Committee, Federal Senate, National Animal Welfare Bill 2005 (2006) [1.64].

82 Philip Jamieson, 'The Legal Status of Animals Under Animal Welfare Law' (1992) 9 Environmental and Planning Law Journal 20.

${ }^{83}$ For more examples of deficiencies in Australian animal law, see Steven White, 'Legislating for Animal Welfare: Making the interests of animals count' (2003) 28 Alternative Law Journal 277.

${ }^{84}$ Christopher D Stone, Should Trees Have Standing? Toward Legal Rights for Natural Objects (1974) 8.
} 
obstacles, it is impossible to adequately grasp the role of lawyers and the nature of the challenges lawyers face. Part IIIB will examine the nature of effective lawyering by outlining the skills lawyers bring to cause advocacy. Finally, Part IIIC will apply the earlier discussion to a case study on battery hens. This case study will provide a concrete, practical example of how lawyers can assist the animal protection cause.

\section{A Appraising the Obstacles}

The role of lawyers within any social justice movement will differ depending on the nature of the opposition to the movement. A cause with widespread public support and well-respected lobby groups may require a different style of lawyer advocacy than an unpopular cause widely viewed as 'extremist' that faces wealthy and powerful opponents.

Aside from its implications for a lawyer's role, analysis of obstacles is also important because, without a sober appreciation of forces that resist change, lawyers in the animal protection movement may become disillusioned and burn out. ${ }^{85}$ Without appraising the movement's obstacles, a young, hopeful idealist could gradually transform into a jaded cynic.

The animal protection movement faces a number of barriers that can at times seem insurmountable. The first is the limitation inherent to legal advocacy. Since the rise of critical legal scholarship and postmodernism, the law is widely viewed as a clumsy vehicle for bringing about social change. ${ }^{86}$ Rather than the law driving progression, legal change usually reflects progress that has already occurred in wider society and merely confirms that progress. ${ }^{87}$ Law is based on the ethical beliefs of society rather than being actively formative of such beliefs. ${ }^{88}$ However, a purely reactionary conception of law would be simplistic. Research has shown that most people uncritically accept the laws and standards of their culture, which indicates that a change in the law may be able to produce a change in social values. ${ }^{89}$ Still, a legal change that is deeply unpopular is unlikely to produce the desired effect on social

\footnotetext{
${ }^{85}$ Richard Delgado and Jean Stefanic, Failed Revolutions: Social Reform and the Limits of Legal Imagination (1994) 145-6.

${ }^{86}$ See, eg, Scott L Cummings and Ingrid V Eagly, 'A Critical Reflection on Law and Organizing' (2001) 48 UCLA Law Review 443.

${ }^{87}$ Nan D Hunter, 'Lawyering for Social Justice' (1997) 72 New York University Law Review $1009,1012$.

${ }^{88}$ David Favre, 'Integrating Animal Interests into Our Legal System' (2004) 10 Animal Law 87,88 .

${ }^{89}$ Susan Finsen, 'Obstacles to Legal Rights for Animals: Can We Get There From Here?' (1997) 3 Animal Law i, iii-iv.
} 
attitudes. Changing the law, albeit important, will always be ancillary to the need to challenge and alter moral beliefs.

Another barrier is economic. In Australia, the egg and chicken meat industries alone are worth several billion dollars per year. ${ }^{90}$ Steven Wise points out that our societies are so economically enmeshed in the use of animals that 'one cannot live and not support the abuse'. ${ }^{91}$ Examples of products that contain animals include fertiliser, plastic, crayons, soaps, shaving cream, paper, matches and tyres. ${ }^{92}$ Challenging practices that contribute so much to human economies is difficult. Paul Waldau notes that 'persuading power holders to relinquish what traditional moral authorities have repeatedly assured them was properly their private property will likely never be an easy task ${ }^{93}$

There are also religious and cultural barriers. The dominant view within the Judeo-Christian tradition is that humans have dominion over all other animals, which justifies almost any treatment of them short of the egregious. While this is changing somewhat, ${ }^{94}$ active concern for animals remains a minority strand in most religious communities. Culturally, a large obstacle in Australia is the trenchant mythology around farmers. Despite the gradual decline of the family farm brought about by the increasing corporatisation of animal agriculture, a critique of farming practices could be interpreted as an attack on the moral integrity of farmers, amounting to cultural blasphemy.

Historical obstacles are also powerful. The historical ideas of animals as inferior and existing for the sake of humanity remain popular. Moreover, in recent history it was mainstream to treat some humans in the ways that we currently treat animals, for instance through subjecting them to "medical experimentation, inhumane captivity, and forced performances for public amusement ${ }^{95}$ Since humans are capable of inflicting unspeakable atrocities on other humans, it is hardly surprising that we continue to inflict atrocities on members of other species.

\footnotetext{
${ }^{90}$ Hon Peter McGauran MP, '\$23 million hatches poultry CRC' (Press Release, 1 October 2003) < http://www.dest.gov.au/Ministers/Media/McGauran/2003/10/ mcg00011003.asp> at 1 June 2008.

${ }^{91}$ Steven Wise, 'Animal Rights, One Step At A Time' in Cass R Sunstein and Martha C Nussbaum (eds), Animal Rights: Current Debates and New Directions (2004) 19, 20.

${ }^{92}$ Ibid.

${ }^{93}$ Paul Waldau, 'Will the Heavens Fall? De-Radicalizing the Precedent-Breaking Decision' (2001) 7 Animal Law 75, 107.

${ }_{94}$ See, eg, Matthew Scully, above n 39; Richard Alan Young, Is God a Vegetarian? Christianity, Vegetarianism, and Animal Rights (1999).

${ }^{95}$ Lovvorn, above n 31, 134-6.
} 
Furthermore, there are psychological barriers to achieving change. Humans are 'accustomed... to treating... animals as mere means to our ends'. Steven Bartlett argues that psychological and conceptual blocks make our resistance to animal rights 'somewhere between difficult to practically impossible'. ${ }^{97}$ Humans are tribal animals that have always drawn sharp boundaries around their moral communities. ${ }^{98}$ The animal protection movement advocates that we undertake the Herculean task of radically extending this boundary.

Animal advocates are drawn from constituencies that ordinarily carry cultural power; the typical animal protectionist is a white, tertiary-educated, urban professional. ${ }^{99}$ Yet opponents of the movement regularly dismiss animal activists as extremists and radicals in an attempt to push animal protection issues out to the margins. ${ }^{100}$ The movement comes up against wealthy, influential and revered opponents such as rural industry lobby groups and the biomedical research establishment, against which it is difficult to compete for public support.

Last, animals differ from many other marginalised groups in that they cannot advocate for themselves. It has been noted that the children's rights movement is asserted in a 'world of adult power'. ${ }^{101}$ In a similar way, animals depend on the support and advocacy of human adults. Peter Singer points out that ' $[t]$ he less able a group is to stand up and organize against oppression, the more easily it is oppressed'. ${ }^{102}$

It is important to recognise that, despite these barriers, a growing number of people are actively challenging the dominant paradigms and undermining the strength of the movement's opponents, not least of which are lawyers. The next section will discuss the nature of effective lawyer advocacy and apply some of the discussion to the animal protection movement. This discussion should assist in setting up Part IIIC, which analyses lawyers' role in

\footnotetext{
${ }^{96}$ Tom Regan, 'The Day May Come: Legal Rights for Animals' (2004) 10 Animal Law 11, 23 4.

97 Steven J Bartlett, 'Roots of Human Resistance to Animal Rights: Psychological and Conceptual Blocks' (2002) 8 Animal Law 143, 176.

${ }_{98}$ Rowan Taylor, 'A Step at a Time: New Zealand's Progress Toward Hominid Rights' (2001)

7 Animal Law 35, 41; Peter Singer, The Expanding Circle: Ethics and Sociobiology (1981).

${ }^{99}$ Lyle Munro, Compassionate Beasts: The Quest for Animal Rights (2001) 7.

${ }^{100} \mathrm{See}$, eg, ABC News Online, 'Animal rights group claims farmed pigs being abused' (2006) $<$ http://www.abc.net.au/news/australia/qld/cairns/200610/s1775927.htm> at 1 June 2008.

${ }^{101}$ Kathleen Funder, 'Children's Rights: Setting the Scene' in Kathleen Funder (ed), Citizen Child: Australian Law and Children's Rights (1996) 2.

${ }^{102}$ Singer, above $\mathrm{n} 16$, v.
} 
achieving change for animals by grounding the earlier discussion in a case study.

\section{B Effective Lawyer Advocacy $1 \quad$ Skills}

Effective lawyer advocacy is built upon the particular skill set that lawyers possess. In order to convince the general public, judges or the legislature to believe in a cause, members of any advocacy group must be able to think objectively about the arguments on both sides of an issue. ${ }^{103}$ They must be able to clearly identify their goals and research the facts and law that will advance them. After being armed with helpful research, they must be able to communicate succinctly and effectively to get across their point of view in the most persuasive manner. They must be driven by passion and empathy. ${ }^{104}$ They must collaborate with like-minded activist networks to achieve the strongest possible team of advocates. ${ }^{105}$

Lawyers have been trained both at university and in the workforce to have some of the above skills. First, lawyers are skilled at advocacy. They are trained to exploit strengths in their clients' arguments and weaknesses in their opponents' arguments by convincingly articulating a case. Second, lawyers are skilled at communicating clearly and logically, sometimes both in written and oral form. Despite lawyers' reputation for verbosity, young lawyers are increasingly trained to communicate succinctly and in plain English. Third, lawyers are skilled at research. Most lawyers are able to get to the heart of an issue by avoiding extraneous detail and can seek out the facts and law necessary to build an argument. Last, lawyers have analytical and objective thinking skills. Lawyers are trained to see both sides of an argument and put aside personal prejudices and biases, at least until they argue for a particular side.

Of course, many non-lawyer advocates have the same skills. Lawyers are neither sufficient nor strictly necessary for a cause to be successful. Furthermore, some lawyers may have qualities that detract from their usefulness, such as stubbornness, arrogance, or a tendency to view social problems entirely in legal terms. Nevertheless, provided lawyers collaborate and work alongside other activists, and do not dominate or override the

\footnotetext{
${ }^{103}$ Leanne Gibbs, Action, Advocacy and Activism: Standing Up For Children (2003) 13.

${ }^{104}$ Ibid 14

${ }^{105}$ Ibid.
} 
important skills of others, lawyers' training and skills can make them indispensable in the pursuit of social justice. For example, Joseph Hawes argues that lawyers were 'the most effective element' in the children's rights movement in the United States. ${ }^{106}$

\section{$2 \quad$ Working within Existing Structures}

Effective lawyer advocacy is also informed by the social position of lawyers. Lawyers are often found in the upper echelons of politics and business. Despite being the target of jokes that portray them as untrustworthy and greedy, lawyers are widely respected. As such, lawyers perhaps more than other activists have a capacity to achieve change within the system, using existing channels of power. Because lawyers understand the justice system, they are well placed to take advantage of its structures for the benefit of the marginalised, such as through lobbying politicians and advancing public interest litigation. Working for change within existing structures of power is derided by some theorists as a 'doomed, moderate' approach that requires too much compromise with an unjust system. ${ }^{107}$ However, Maddison and Scalmer note the possibilities of radical and moderate wings of a movement employing a 'division of labour': 108

$[\mathrm{R}]$ adicals demand attention and provoke antipathy. Their adventures shake up the powerful and foment controversy; their interventions polarise and publicise. In contrast, reformists offer a sane, rational alternative. They cool passions with sensible suggestions. They seek the practical compromise. In this way, the revolutionary creates a space where the moderate can bargain. Governments fear the extremists and meet with the reformists. Strategic divisions within the movement can become, briefly, a kind of political resource.

Lawyers are in a strong position to act as a 'moderate wing' of the animal protection movement. Their admission oath to obey and uphold the law makes radical civil disobedience difficult. Indeed, by temperament and training most lawyers are inclined to obey the law anyway and work for change from within. While other animal activists may continue to generate

\footnotetext{
106 Joseph M Hawes, The Children's Rights Movement: A History of Advocacy and Protection (1991) 110 .

107 Richard Delgado, 'Our Better Natures: A Revisionist View of Joseph Sax's Public Trust Theory of Environmental Protection, and Some Dark Thoughts on the Possibility of Law Reform' (1991) 44 Vanderbilt Law Review 1209, 1212; Francione, above n 32, 164.

${ }^{108}$ Maddison and Scalmer, above n 45, 150-1 (emphasis added).
} 
controversy through illegal acts such as breaking into factory farms, ${ }^{109}$ lawyers can provide a cool voice of reason to temper the perception of animal advocates as extremists.

The legal system and the law are inherently conservative. The law preserves the status quo and is not amenable to revolutionary arguments. The shock and awe tactics of some wings of the animal protection movement work better for changing social attitudes. These wings confront people with footage of cruelty, appeal to their emotions, and stir up outrage and compassion. The law does not respond in the same way as the general public to emotive appeals, so a rough division of labour within the movement seems worthwhile.

\section{$3 \quad$ Learning from Others}

Effective lawyer advocates also learn from other social justice movements. A particularly successful cause of late is the environmental movement. The environmental movement demonstrates the important role of science in legal argument. The presentation of legal arguments backed up by detailed and accurate ecological science and empirical research has contributed significantly to the success of environmentalism in the law. ${ }^{110}$ Similarly, environmentalists have cleverly packaged some arguments in human-centred terms, even while trying to extend consideration to non-human entities. We have seen this recently with arguments that climate change will have devastating effects on human communities, as well as arguments around impacts on human health and tourism if the environment is not protected. ${ }^{111}$

Animal lawyers are advised to use similar strategies wherever possible. For example arguments for greater penalties in animal welfare statutes could be based on research that links violence against animals to violence against humans. ${ }^{112}$

\footnotetext{
${ }^{109}$ See, eg, Open Rescue, About Open Rescue $<\mathrm{http}$ ://www.openrescue.org/ about/index.html $>$ at 1 June 2008.

${ }^{110}$ David Favre, 'Time for a Sharper Legal Focus' (1995) 1 Animal Law 1, 4; Samuel P Hays, A History of Environmental Politics Since 1945 (2000) 202.

${ }^{111}$ Samuel P Hays, A History of Environmental Politics Since 1945 (2000) 29, 200.

112 Katrina Sharman, 'Sentencing Under Our Anti-cruelty Statutes: Why Our Leniency Will Come Back To Bite Us' (2002) 13 Current Issues in Criminal Justice 333.
} 
Legal arguments for animal protection generally should be supported by rigorous research in veterinary science, biology, psychology and so on. ${ }^{13}$ By co-opting the authoritative discourse of science to the animal protection cause, the movement will achieve legal success much more quickly than if it relies solely on philosophical argument.

\section{$4 \quad$ Theory}

Last, effective lawyer advocacy is grounded in a strong theory and explicit goal. A lawyer who supports animal welfarism will have a different goal than a lawyer who supports animal rights. This paper has offered the capabilities approach as a theoretical structure. Accordingly, for those who agree with the capabilities approach, effective lawyer advocacy will be consistent with the desire to allow animals the space to flourish in their characteristic form of life. For advocates who reject the capabilities approach, their lawyering should be consistent with whatever theory they support.

\section{Battery Hens}

Part IIIC will show how lawyers can apply their skills to a practical project for the benefit of animals.

\section{Introduction to the Problem}

Over 13 million hens are used for egg production in Australian farms at any given time. Approximately $80 \%$ of these hens are kept in battery cages while the remainder are kept in 'barn' or 'free range' systems that allow hens some modicum of freedom of movement.

Battery hens are kept indoors in large sheds for the duration of their lives. They are housed in barren wire cages with up to five other chickens, providing each chicken with individual space of less than an A4 sheet of paper. This is the closest confinement of any form of animal agriculture. Battery hens are also subjected to 'beak trimming', a procedure that painfully removes a portion of their sensitive beaks without anaesthetic. This is undertaken in order to prevent cannibalism, itself a corollary of overcrowding and stress.

\footnotetext{
${ }^{113}$ Steven M Wise, 'Animal Thing to Animal Person-Thoughts on Time, Place and Theories' (1999) 5 Animal Law 61, 63.
} 
The intensive nature of the farming leads to a number of significant welfare problems. The battery cage prevents hens from carrying out their most basic behavioural needs, such as stretching their wings, perching, dust-bathing and laying eggs in nests. According to the European Scientific Veterinary Committee (ESVC), the battery cage has 'inherent severe disadvantages for the welfare of hens' including the prevention or modification of natural behaviours, increased fear, and bone weakness caused by lack of movement. ${ }^{114}$ A substantial number of battery hens have broken bones by the time they are slaughtered, and experience 'high fear levels' and 'substantial stress responses' when being handled by humans during the slaughter process. ${ }^{115}$ It is no wonder that the ESVC states that '[a] better system for housing hens is clearly needed'. 116

\section{Progress Already Made}

Of all issues in farm animal welfare, the plight of battery hens is probably the most widely understood by the Australian public. Animal activists have campaigned on battery hens for quite some time. The RSPCA recently launched an advertising campaign on television with the slogan 'don't make hens pay for your eggs'. ${ }^{117}$ Animals Australia and the various Animal Liberation groups vigorously campaign on this issue as well.

The wider availability of free-range eggs in Australian supermarkets is testament to the growing consumer awareness of cruel practices in the egg farming industry. This awareness has also entered our universities. The University of Newcastle recently announced that it would no longer serve cage-laid eggs on campus. Students at other Australian universities are currently campaigning to have their campuses provide similar undertakings.

Governments are beginning to take notice. The Australian Capital Territory Government recently granted major egg producer Pace Farms \$1 million to make the transition from battery farming to barn farming, which would allow

\footnotetext{
${ }^{114}$ Commission of the European Communities, 'Report of the Scientific Veterinary Committee Animal Welfare Section on the Welfare of Laying Hens' (1996) <http://ec.europa.eu/ food/fs/sc/oldcomm4/out33_en.pdf> 109 at 1 June 2008.

$115 \mathrm{~J}$ L Barnett and E A Newman, 'Review of welfare research in the laying hen and the research and management implications for the Australian egg industry' (1997) 48 Australian Journal of Agricultural Research 385, 392-4.

${ }^{116}$ Commission of the European Communities, above n 115, 103. See also M Baxter, 'The welfare problems of laying hens in battery cages' (1994) 134(24) The Veterinary Record 6149.

${ }^{117}$ RSPCA Australia, Choose Wisely <http://www.rspca.org.au/campaign/ choosewisely.asp> at 1 June 2008.
} 
hens to roam around inside a shed. According to Chief Minister Jon Stanhope, this was designed to 'phase out battery egg production in the ACT' and change the purchasing behaviour of ACT residents. ${ }^{118}$

Internationally, there has been significant advancement in this area. The conventional battery cages that exist in Australia are currently being phased out in the European Union under Council Directive 1999/74/EC, with a total ban to be in place by 2012. All cage systems are effectively prohibited in Switzerland. ${ }^{19}$ Other countries that have taken steps to ban or phase out the barren battery cage include Sweden, Finland, Switzerland, Norway, Germany and Austria. ${ }^{120}$

Unfortunately no Australian government has yet supported an outright ban on battery cages. Instead, governments tend to support piecemeal and largely useless measures such as increasing cage space by minuscule proportions. For example, in 2001 the cage space allowance for each hen under the Code of Practice for the Welfare of Poultry was increased from $450 \mathrm{~cm}^{2}$ to $550 \mathrm{~cm}^{2}$, with an allowance of 20 years from the date of manufacture or until 1 January 2008 (whichever is the later) for producers to decommission or modify the smaller cages. $^{121}$

Lawyers and other concerned advocates need to apply significant pressure to governments to follow the lead of European nations and implement a phasedout ban of the battery cage.

\footnotetext{
118 Jon Stanhope, $\$ 1$ million offer to Pace to abandon battery cages, <http://www. chiefminister.act.gov.au/media.asp? media $=2959 \& \mathrm{id}=2959 \&$ section $=24 \&$ title=Jon\%20Stanhop e, $\% 20$ MLA $>$ at 1 June 2008.

${ }^{119}$ There is not an outright ban on cage systems in Switzerland, but Swiss law requires welfare standards for birds that are impractical in cages so cages are no longer used: see Heinzpeter Studer, How Switzerland got rid of battery cages (2001) Pro Tier International $<$ http://www.upc-online.org/battery_hens/SwissHens.pdf > at 1 June 2008.

120 See, eg, Animals Australia, Battery Hens <http://www.animalsaustralia.org/freebetty/ battery_hens.php> at 1 June 2008; Gaverick Matheny and Cheryl Leahy, 'Farm-animal welfare, legislation, and trade' (2007) 70 Law and Contemporary Problems 325, 340; Albert E Pope, Austrian Parliament Votes Unanimously to Ban Battery Cages! (2004) United Poultry Concerns Inc. <http://www.upc-online.org/ battery hens/52804austria.htm> at 1 June 2008; Veronica Hirsch, Overview of the Legal Protections of the Domestic Chicken in the United States and Europe (2003) <http://www.animallaw.info/articles/ovuschick.htm> at 1 June 2008.

121 Primary Industries Standing Committee, Model Code of Practice for the Welfare of Animals: Domestic Poultry (4 ${ }^{\text {th }}$ ed, 2002) [2.3.2.1].
} 


\section{$3 \quad$ Worth Pursuing?}

There are a number of reasons why Australian animal lawyers should support the abolition of the battery cage.

This project is consistent with the capabilities approach. The very behaviours that constitute a chicken's natural life-scratching, perching, dust-bathing and so on-are thwarted by the battery cage.

Because there is already public knowledge of the issue and a considerable amount of campaigning that has already been underway, lawyers do not have to reinvent the wheel. Advocates can draw upon the substantial repository of local and international know-how, particularly from European organisations that pressured the European Union to phase out battery cages.

Intensive farming has always been and will continue to be a major battleground in relation to animal protection. The entire edifice of factory farming will not crumble in the short term, so animal advocates must attack points of weakness in the system rather than fight to pull down the whole structure. Battery cages are a point of weakness due to the significant pressure that has already been placed on industry. It is also one of the few areas in farming where governments have displayed some willingness to consider reform.

\section{$4 \quad$ Lawyers' Role in the Project}

Lawyers have a significant role to play in abolishing battery cages in Australia.

Lawyers should analyse and think objectively about the likely arguments of their opponents. It is possible that some opponents may deny that battery hens suffer. ${ }^{122}$ However, opposition to a ban will likely focus on two arguments. The first is economic. This argument will draw attention to the higher price consumers will be forced to pay for eggs and the alleged infeasibility of servicing consumer demand through free range farming. The second is welfarist. This argument will claim that free range farming has welfare problems as well. Accordingly, this argument will attempt to roughly equate all forms of egg production in the hope that consumers and

122 Des Houghton, Feathers fly on caged chooks, The Courier Mail <http://www. news.com.au/couriermail/story/0,23739,22067974-27197,00.html $>$ at 1 June 2008. 
governments will shrug their shoulders and opt for maintenance of the status quo.

Such arguments need to be tackled directly rather than ignored or sidelined. The scientific research on hen welfare should be comprehensively analysed, even the research that downplays the problems with battery cages and exaggerates the problems with free range systems. Similarly, the economic data on the cost of implementing a battery cage ban should be examined, and surveys should be conducted to support the argument that consumers will pay extra for eggs that are produced more ethically. Because these issues are outside a lawyer's expertise, it is perhaps worth outsourcing these matters to people with scientific, economic and marketing knowledge.

Lawyers should use their research skills to ascertain how gains have been made for battery hens in overseas jurisdictions and apply those lessons in the Australian context. After learning from overseas practitioners, Australian lawyers should use their skills in communication and advocacy to present the case for the abolition of battery cages logically and persuasively, identifying all the strongest arguments and recording them clearly in submissions to relevant government bodies.

Lawyers should collaborate with existing organisations that are actively campaigning on battery hens, such as Animals Australia, Voiceless, the RSPCA and various state-based Animal Liberation groups. Some of these organisations already have in-house lawyers, but external lawyers can offer pro bono services to assist them, as some leading Australian law firms are already doing. Most of the abovementioned groups have put considerable effort into cultivating an 'insider' image, representing themselves as moderate, reasonable and worth consulting on animal issues. Increasing the number of lawyers in these bodies can only assist in further consolidating their reputation as sensible organisations, hopefully without detracting from the passion and vigour with which they advocate for the animal protection cause.

Moreover, lawyers could join dedicated bodies such as the Barristers' Animal Welfare Panel and Lawyers for Animals in Victoria. Lawyers for Animals is experienced at submission writing and lobbying all levels of government, while the Barristers' Animal Welfare Panel has generated formidable influence in litigation, lobbying, and advising governments, political parties and animal organisations. Drawing upon the human resources and expertise of these and other like bodies will substantially increase the chances of lawyers succeeding on projects such as the abolition of the battery cage. 
Lawyers should identify parties and individuals within Australian parliaments that will support the cage's abolition. ${ }^{123}$ This may include the Australian Greens, who already support the phase-out of intensive farming practices, ${ }^{124}$ and individual members from the two major political parties. Lawyers should notify these people of the campaign, in order to build support within Australian legislatures.

Lawyers should utilise the media in conjunction with other campaign supporters to generate favourable public sentiment. Lawyers should submit opinion pieces, press releases and letters to the editor. Wherever possible they should use emotion to generate a scandal and marshal sympathy, ${ }^{125}$ such as by telling stories of particularly appalling cruelty found inside factory farms. It is perhaps advisable to launch a media campaign prior to a legislative campaign so that there is a spotlight on governments, making it difficult for them to avoid tackling the issue.

\section{CONCLUSION}

It has been observed that every social movement goes through three stages: ridicule, discussion and ultimately, adoption. ${ }^{126}$ While still ridiculed in some quarters, the animal protection movement is now firmly in the 'discussion' phase amongst Australian lawyers. Justice Michael Kirby has noted that concerns about animal welfare 'are clearly legitimate matters of public debate across the nation'. ${ }^{127}$

Even if particular projects such as the abolition of the battery cage are not initially successful in legal terms, they will still have generated publicity, raised consciousness of the plight of animals and mobilised the movement, all of which lay the groundwork for more effective legal activism in the future. ${ }^{128}$ With the hard work and dedication of animal lawyers, working alongside other activists, their vision of a more just, humane and compassionate society may one day be reflected in our statute books. This will make the struggles, disappointments and frustrations of lawyering for animals worthwhile.

\footnotetext{
123 Public Interest Law Institute, Pursuing the Public Interest: A Handbook for Legal Professionals and Activists (2002) 125.

124 The Australian Greens, Animals Policy <http://greens.org.au/about/policy/policy.php? policy_id=18> at 1 June 2008 .

${ }^{125}$ Randy Shaw, The Activist's Handbook (1996) 155.

${ }^{126}$ Al Johnson, 'Animal Rights Cause Gains Credibility' (1995) 1 Animal Law 11, 11.

${ }^{127}$ ABC v Lenah Game Meats (2001) 208 CLR 199, 287.

${ }^{128}$ Helena Silverstein, 'The Legal Status of Nonhuman Animals' (2002) 8 Animal Law 1, 68.
} 